\title{
NEGATIVE EFFECTS OF TREBLE DAMAGE ACTIONS: REFLECTIONS ON THE NEW ANTITRUST STRATEGY
}

\author{
ARTHUR D. AUSTIN*
}

Since the passage of the Sherman Act $^{1}$ in 1890 , private parties have had the right to seek monetary compensation for injuries to business or property resulting from antitrust violations. ${ }^{2}$ By allowing plaintiffs to treble their damage awards, Congress sought to provide the private sector with the incentive to function as a self-policing system $^{3}$ - the conventional assumption being that the plaintiff's sole objective in a treble damage action would be to extract monetary compensation from the defendant.

Events unfolding over the past decade indicate that this compensation assumption is obsolete. Under the "new" antitrust strategy, management intentionally exploits the private suit to achieve noncompensatory objectives. Treble damage complaints are now filed in an attempt to intimidate defendants into modifying their conduct in a way favorable to the interests of the plaintiff. The objective of the strategy is to cause the defendant to "soften" the vigor of its competitive tactics. The plaintiff assumes that a risk-conscious defendant will acknowledge the ambiguities of antitrust precedent, recognize the uncertainty of the outcome and, as a result, will avoid taking the chance of exacerbating potential damages by continuing the allegedly illegal conduct. Faced with this prospect, the defendant typically gives the plaintiff various "business advantages" (such as supply contracts) in lieu of a monetary settlement. Thus, the new antitrust strategy has

* Edgar A. Hahn Professor of Jurisprudence, Case Western Reserve University School of Law. B.S. 1958, University of Virginia; LL.B. 1963, Tulane University School of Law.

1. Act of July 2, 1890, ch. 647, 26 Stat. 209 (current version at 15 U.S.C. $\S \S 1-7,15$ (1976)).

2. 15 U.S.C. $\$ 15$ (1976) provides that "[a]ny person who shall be injured in his business or property by reason of anything forbidden in the antitrust laws may sue . . and shall recover threefold the damages by him sustained, and the cost of suit, including a reasonable attorney's fee."

3. W. Hamilton \& I. Till, Antitrust in Action 10, 82 (TNEC Monograph No. 16, 1940). The treble damage action is thought to produce three positive effects: deterrence, compensation and plaintiffs serving as private attorneys general. Illinois Brick Co. v. Illinois, 431 U.S. 720, 745-47 (1977); see Report OF the ATroRney General's National Committee to StUdy THE ANTITRUST LaWs 378 (1955). 
achieved its noncompensatory goal.

This new antitrust strategy produces at least three detrimental effects. Existing problems, such as depletion of resources within the judicial system and the drain on corporate energies, are aggravated. The "softening" of competition in areas such as pricing has deleterious effects-particularly in highly concentrated industries. Finally, settlements that establish business relationships between rivals at a minimum can encourage a "quiet life" and, at the worst, constitute illegal restraints of trade.

This Article surveys the new antitrust strategy. The discussion proceeds through five parts: the first two sections recite the factors that coalesced to produce the new strategy, while the third section describes its emergence as a tactical weapon. The fourth part analyzes the effects of this strategy on competition, and the conclusion summarizes recommendations for remedying the situation.

\section{The Origins of the New Antitrust Strategy}

The impetus for the new antitrust strategy came from three sources: first, managers overcame an entrenched bias against suing a fellow member of the executive suite "club"; second, the Supreme Court embraced a blend of economic theory and populism in an effort to encourage private antitrust enforcement; and, third, the reform movement "discovered" antitrust and educated the public to its flexibility.

\section{A. Antitrust Evolution and the Demise of the "Old Club Tradition."}

Antitrust ideology has evolved through three "generations." During the first generation the judiciary sought to settle on a workable interpretation of the newly enacted Sherman Act. ${ }^{4}$ This generation ended in 1911 with the break-up of Standard Oil in an opinion that introduced the flexible "rule of reason" as the primary guide for judicial interpretation. ${ }^{5}$ During the second generation, extending from the time of the Standard Oil case until the 1945 decision of United States $v$. Aluminum Co. of America (Alcoa), ${ }^{6}$ illegality was determined by the presence of "abusive" conduct-the beneficent monopolist was spared while the abusive bully was deemed a violator. ${ }^{7}$ The third generation

4. See, e.g., W. Letwin, LAW and Economic Policy in America: The Evolution of the Sherman Act (1965); H. Thorelli, The Federal Antitrust Policy: Orioination of aN AMErican Tradition (1955).

5. Standard Oil Co. v. United States, 221 U.S. 1 (1911).

6. 148 F.2d 416 (2d Cir. 1945).

7. United States v. United States Steel Corp., 251 U.S. 417, 448 (1920). 
was conceived in the Alcoa decision when Judge Hand rejected the "abuse" doctrine and channeled economics into antitrust ideology. ${ }^{8}$ Thereafter, the concept of market power rather than abusive conduct served as the main theme in determining illegality. ${ }^{9}$

Antitrust litigation by either the government or private parties was infrequent during the first and second generations of antitrust ideology. ${ }^{10}$ Of the suits initiated, most were government actions. ${ }^{11}$ The paucity of private actions was due to the formidable burdens of proof set by such harsh tests as the "abuse" doctrine and a reluctance to violate the code of the executive suite by suing "one of the boys." "[W] hen an executive felt abused by 'monopolistic' competition, he took his medicine quietly, if not altogether sportingly." 12 By sharp contrast, the third generation bristles with private litigation; ${ }^{13}$ as one experienced practitioner has observed: "Perhaps the most visible change in the nature of antitrust practice in recent years has been in the sheer magnitude of treble damage litigation." 14

The demise of the "old club" tradition began with an avalanche of private actions triggered by government convictions in the "electrical conspiracy" price-fixing cases of the early $1950 \mathrm{~s}^{15}$ Because of the widespread publicity given the government actions, management feared shareholder suits if they failed to assert obvious antitrust claims. ${ }^{16}$ However, these fears alone did not account for the burgeoning of treble damage litigation. By far the most influential stimulus for increased resort to the private action came from two additional factors: the populist tendencies of the Warren Court and the complete assimilation of economics by the judiciary.

8. A.D. Neale has described Alcoa as "clearly one of the high-water marks of antitrust . . ." A. Neale, The Antitrust Laws of the United States of America 112 (2d ed. 1970).

9. See Rostow, The New Sherman Act: A Positive Instrument of Progress, 14 U. CHI. L. REv. 567 (1947).

10. Between 1890 and 1938 , private parties filed 175 complaints, only 13 of which were successful. 1 S. WHITNEY, ANTITRUST PolicIES 21 (1958). For a comprehensive statistical analysis, see Posner, A Statistical Study of Antitrust Enforcement, 13 J.L. \& ECON. 365 (1970).

11. Between 1890 and 1944, the Justice Department filed 630 complaints and the FTC filed 723 (restraint of trade), while private parties filed 693 actions. Posner, supra note 10, at 365-71.

12. Holsendolph, New Challenges in Antitrust, N.Y. Times, Jan. 21, 1973, § 3, at 1, col. 1.

13. In 1960 the government filed 87 complaints in federal courts; private parties filed 228 . In 1977 the government filed 78 actions in federal courts while private actions totaled 1,611. TRADE REg. REP. (CCH) No. 302, at 7 (Oct. 13, 1977).

14. Handler, The Shift from Substantive to Procedural Innovations in Anti-Trust-The TwentyThird Annual Antitrust Review, 71 ColuM. L. Rev. 1, 4 (1971).

15. Id. 4-5; Special Report: Is John Sherman's Antitrust Obsolete?, Bus. WeEk, Mar. 23, 1974 , at 47,54 .

16. See C. Bane, The Electrical Equipment Conspiracies 50 (1973). 


\section{B. Economics and Populism in the Supreme Court.}

By 1960 , Alcoa's influence had proved decisive; economics had become the mainspring for resolving antitrust cases. Conditioned by the government's persistent use of the economic brief, ${ }^{17}$ courts began to rely upon a priori economic theory as the most convenient tool to bridge the gap between complicated evidence and the ultimate issue of liability. ${ }^{18}$ The Warren Court adopted the economic brief but blended in a form of populism that exalted freedom of entry and equality of opportunity in the marketplace. ${ }^{19}$ Among the lower courts, it became fashionable to evaluate market structure and then, under the guidance of Industrial Organization Economics, ${ }^{20}$ to render near-conclusive assumptions on conduct and performance. ${ }^{21}$

These approaches resulted in a new set of proscriptive standards that favored plaintiffs and in a new antitrust consciousness among managers:

[B]oth directly and through its encouragement of public and private enforcement, the Court has made the business community more aware of antitrust than ever before. No major American corporation would consider a merger today without first consulting antitrust counsel. Businessmen now commonly talk about antitrust; internal compliance programs have been initiated and carried out. One cynical friend suggests that antitrust is now the second most talked about subject among businessmen, the favorite still being prices!22

\section{The Reform Movement Pushes Antitrust to the "Outer Fringes."}

Private antitrust activity received further encouragement when various reform interests appropriated the antitrust laws to serve as instruments for restructuring society. ${ }^{23}$ Reformers have advocated an

17. See Austin, A Priori Mechanical Jurisprudence in Antitrust, 53 MINN. L. REv. 739 (1969).

18. Economic theory was exalted to the point that one commentator observed that "a rule of law is required to be more consistent with economic theory than with past precedent." Brodley, Oligopoly Power Under the Sherman and Clayton Acts-From Economic Theory to Legal Policy, 19 STAN. L. Rev. 285, 298 (1967).

19. See Kauper, The 'Warren Court' and the Antitrust Laws: Of Economics, Populism, and Cynicism, 67 Mich. L. Rev. 325 (1968).

20. Industrial Organization Economics is the study of the factors that determine market performance of firms and industries, e.g., conditions of supply and demand, market structure and conduct. See F. Scherer, Industrial Market Structure and Economic Performance 2-6 (1970).

21. For an egregious example of the assumption of illegal conduct and effects from market structure see Allis-Chalmers Mfg. Co. v. White Consol. Indus., Inc., 414 F.2d 506 (3d Cir. 1969), cert. denied, 396 U.S. 1009 (1970).

22. Kauper, supra note 19, at 335; see Carruth, The "Legal Explosion" Has Left Business Shell-Shocked, ForTuNe, Apr. 1973, at 65.

23. Ralph Nader set the tone by announcing that "from the present on, antitrust and its brace of phrases will start to become household words . . . ." M. GREEN, B. MOORE, JR. \& B. WASSER- 
extremely broad range of objectives for antitrust law. ${ }^{24}$ Ralph Nader believes that section 7 of the Clayton Act could be used to put an end to "dehumanizing" assembly lines and to deconcentrate markets, thereby erasing racial discrimination. ${ }^{25}$ The late Senator Hart argued that those who violate environmental protection laws should be charged with engaging in unfair methods of competition under the Federal Trade Commission Act. ${ }^{26}$ The FTC is conducting an antitrust campaign against "manipulative" advertising, ${ }^{27}$ while the Justice Department has made an effort, albeit unsuccessful, to attack organized crime under the antitrust laws. ${ }^{28}$

Private parties have embraced the reformists' visions of antitrust law as a multidimensional instrument capable of achieving diverse goals. The Wall Street Journal has observed that it is the private plaintiff who is blazing the new trails: "Increasingly . . . private plaintiffs are using antitrust law as far more than a remedy for unreasonable restraint of trade in its traditional sense." 29 Some of the more innovative private actions have sought to enjoin the enforcement of uniform building codes, ${ }^{30}$ to force adherence to affirmative hiring policies ${ }^{31}$ and to prevent the alleged monopolistic practices of a charity. ${ }^{32}$ The malleability of antitrust doctrines has encouraged parties to use the laws in unique ways. Such use, however, has injected a degree of uncertainty into the outcome of such cases.

\section{EXPLOITING RISK AND UNCERTAINTY}

Negative attitudes towards risk furnish the leverage for the use of the new antitrust strategy. Evidence from business management studies, supported by socioeconomic literature, indicates that management

Stein, The Closed EnTERPRISE System iv (1971). Business Week corroborated Nader's prediction: "[O]nly a decade ago historian Richard Hofstadter wrote, "the antitrust movement is one of the faded passions of American reform.' Today it is the darling of reform." BUs. WeEK, Mar. 23, 1974 , at 47.

24. See Austin, The Emergence of Societal Antitrust, 47 N.Y.U.L. REv. 903 (1972).

25. M. Green, B. Moore, Jr. \& B. Wasserstein, supra note 23; see Marcus, Civil Rights and the Anti-trust Laws, 18 U. CHI. L. Rev. 171 (1951).

26. Hart, The Quality of Life and the Antitrust Laws: A View from Capitol Hill, 40 ANTITRusT L.J. 302, 305 (1971).

27. Wall St. J., Dec. 28, 1977, at 24, col. 1.

28. See Note, Antitrust Enforcement Against Organized Crime, 70 Colum. L. Rev. 307 (1970).

29. Wall St. J., Jan. 18, 1972, at 1, col. 6.

30. $I d$.

31. Antitrust \& Trade Reg. Rep. (BNA), No. 635, at A-16 (Oct. 23, 1973); id., No. 804, at A-5 (Mar. 8, 1977).

32. N.Y. Times, Aug. $21,1977, \S 1$, at 26 , col. 1-2. 
is generally averse to risk. ${ }^{33}$ Risk aversion manifests itself in a firm's commitment to extensive planning as a means of controlling the uncertainties of the future and in a general avoidance of situations involving risk.

Risk taking is popularly assumed to be an important source of energy for capitalism. The accepted convention is that free enterprise was initially fueled by flamboyant personalities who purposely confronted and defied risk in building industrial dynasties and amassing great fortunes. Yet an accurate interpretation of history reveals that the actions of the Goulds and Drews were mere footnotes to the main text of chapters dealing with the efforts of entrepreneurs to control risk.

The most significant development in the struggle to deal with risk occurred around the turn of the century when strong-willed individuals such as John D. Rockefeller and Andrew Carnegie created great consolidations of firms and, in the process, professionalized management. ${ }^{34}$ The genius of the early entrepreneurs was in coordinating the differing organizational charts of the merging firms into efficiently run, single enterprises. $^{35}$ The novel problems of large consolidations made it impossible for the "rugged individualist" entrepreneur to manage effectively without help - hence the appearance of a new class of administrators who had little, if any, ownership in the firm and whose primary function was to "manage." 36

The full significance of the split between ownership and management received universal recognition in the 1932 Berle and Means study. ${ }^{37}$ Their work identified a new managerial class, free from control by passive shareholders. The significance of the "split" is that while both groups may share a common interest in profits, managers are also driven by other aspirations. The primary goals of the management class are continued growth ${ }^{38}$ and the survival of the firm, ${ }^{39}$ both

33. See Breit \& Elzinga, Antirust Penalties and Attitudes Toward Risk: An Economic Analysis, 86 HARv. L. REv. 693, 704-06 (1973).

34. Maurer concludes that these individuals saw corporate organization as involving something "more challenging than personal ambition." H. MAURER, GREAT ENTERPRISE: GrowTH AND BEHAVIOR OF THE BIG CORPORATION 47 (1955).

35. Chandler traces modern management to the early consolidation wave, where complex administrative problems were resolved by paid managers who had little stock ownership in the new company. A. Chandler, The Visible Hand: The Managerial Revolution in AmeriCAN BUSINESS 415 (1977).

36. $I d$.

37. A. Berle \& G. Means, The Modern Corporation and Private Property (1932).

38. "The second imperative of the oligarch's theory of management is corporate growth. Mortimer believed the chief executive needs bifocal glasses . . to see profit as the short-range benefit for the company and growth as its long-range goal." D. FINN, THE CORPORATE OLIGARCH 128 (1969).

39. "But [the corporation's] basic purpose is simply to exist-to survive business cycles, to 
of which require effective planning.

Although the market system continues to attract strong personalities, their energies now are channeled into group management ideology, where the chief executive's primary role is to organize expertise and institute consensus judgments. ${ }^{40}$ Expertise is derived from a range of disciplines, all capable of delivering accurate information on market trends. New techniques in psychology and sociology allow firms to ascertain consumer inclinations with a high degree of accuracy. ${ }^{41}$ Constantly improving technology expands the scope of knowledge and thereby reinforces "planning intense" attitudes. ${ }^{42}$ As a result, the planning function has become a highly professionalized science that repudiates individualism and hunch taking while encouraging a bureaucratic mentality that exalts caution. ${ }^{43}$

Risk is anathema to the most vulnerable target of the new antitrust strategy-the large firm. Since every decision by a large firm involves a heavy commitment of resources, errors jeopardize or completely subvert growth and survival. The planning "ideal" thus becomes control over all events. ${ }^{44}$ Under these conditions, managers are dedicated to planning so as "to minimize uncertainty, to minimize the consequences of uncertainty, or both." 45

overcome inefficiency and avoid error . . . and to live beyond the lives of the men who are part of it." H. Maurer, supra note 34, at 168; see H. Koontz \& C. O’Donnell, Principles of MaNAGEMENT 10 (4th ed. 1968).

40. Harold Geneen, a legend among contemporary managers, describes the ITT dedication to group judgments:

More than 200 days a year are devoted to management meetings at various organizational levels throughout the world. In these meetings . . . decisions are based on logic-the business logic that results in making decisions which are almost inevitable because all the facts on which the decisions must be based are available. The function of the planning and the meetings is to force the logic out into the open where its value and need can be seen by all.

A. Sampson, The Sovereign State of ITT 129-30 (1973).

41. See generally N. Borden, Advertising IN OUR EConomy (1945); E. BrinK \& W. KeLley, The Management of Promotion (1963); S. Otteson, W. Panschar \& J. Patterson, Marketing: The Firm's Viewpoint (1964); V. Packard, The Hidden Persuaders (1957).

42. See D. Bell, The Coming of the Post-Industrial Society 197 (1963).

43. Gordon concludes that the professional manager, unlike the "entrepreneur," is cautious and relies heavily on systematic research and planning. R. GoRDON, BUSINESS LEADERSHIP IN the LaRge Corporation 322, 324 (1961). He also notes that directors are more cautious than executives: "Even more than executives, directors have personally little to gain and much to lose from approving decisions involving a high degree of risk." Id. 329-30 n.21. Gordon's views are supported by Breit \& Elzinga, supra note 33, at 704-06.

44. Galbraith argues that this has, in fact, occurred under a technostructure of giant firms that have expertly used planning techniques to gain freedom from the pressures of the market, government and shareholders. J. Galbraith, The New Industrial STAte (1967).

45. R. Marris, The Economic Theory of "Managerial" Capitalism 232 (1964). 


\section{Risk Aversion: The New Antitrust Strategy Applied}

\section{A. Uncertainty and Risk in Antitrust Litigation.}

Despite the skills of management, what Fortune describes as the "Disneyland of antitrust" 46 constitutes a hazard that defies effective risk control. "No matter how good his intentions, no matter how conservative and cautious his course after conferring with attorneys, the risk of antitrust violation by a decision maker is always present." 47 The consensus among managers is that any complaint filed against the firm presents a high risk of producing a loss of resources. Exploiting this assumption, some firms use the antitrust complaint as an offensive weapon to compel risk-averting defendants to modify their behavior so as to avoid liability or to avoid enhancing possible damages. Moreover, confronted with the necessity to modify behavior, defendants will adopt a favorable attitude toward settlement.

The new antitrust strategy achieves optimum effectiveness when the complaint attacks the legality of conduct that plays a critical role in the defendant's competitive success and that is subject to unpredictable legal treatment. A firm's conduct in setting prices satisfies these conditions. Pricing is an everyday event that attracts frequent and scholarly study yet remains shrouded in mystery and controversy. ${ }^{48}$ Whether firms price to maximize profits, whether they "administer prices" or succumb to "mutual interdependence," are questions that have incited copious, but inconclusive, commentary. Recently the controversy has focused on the legality of such tactics as "limit" pricing, "umbrella" pricing and "predatory" pricing. ${ }^{49}$

As a result of vague and inconsistent judicial treatment, dominant firms risk liability regardless of the pricing strategy they adopt. Professor Scherer interprets Judge Hand's opinion in Alcoa as condemning limit pricing. ${ }^{50}$ Professor Posner threads together the United States $v$.

46. Guzzardi, A Search for Sanily in Antitrust, FortunE, Jan. 30, 1978, at 72, 73. Guzzardi observes that the antitrust laws "have become the most baffling and unpredictable of all the doctrines originated by government to control the behavior of business." Id. 73.

47. Mussman, Antitrust Risk Taking by the Executive, 44 ANTITRust L.J. 394, 395 (1975).

48. See, e.g., P. Asch, Economic Theory AND the Antitrust Dilemma (1970); F. SCHERER, supra note 20; Bernhard, Competition in Law and Economics, 12 ANTITRUST BuLl. 1099 (1967); Posner, Oligopoly and the Antitrust Laws: A Suggested Approach, 21 Stan. L. REv. 1562 (1969); Turner, The Definition of Agreement Under the Sherman Act: Conscious Parallelism and Refusals to Deal, 75 HARv. L. REv. 655 (1962).

49. See Areeda \& Turner, Predatory Pricing and Related Practices Under Section 2 of the Sherman Act, 88 HARv. L. REv. 697 (1975); Posner, Exclusionary Practices and the Antitust Laws, 41 U. CHI. L. Rev. 506 (1974); Scherer, Predatory Pricing and the Sherman Act: A Comment, 89 HaRv. L. Rev. 869 (1976); Williamson, Predatory Pricing: A Strategic and Welfare Analysis, 87 YALE L.J. 284 (1977).

50. F. SCHERER, supra note 20 , at 460 . 
United States Steel Corp. ${ }^{51}$ Alcoa, and United States v. United Shoe Machinery Corp. ${ }^{52}$ decisions for the proposition that umbrella pricing is preferred over limit pricing. ${ }^{53}$ The risks involved in any decision to undertake a pricing strategy are emphasized by Professor Dewey, who concludes that, under Alcoa, umbrella and limit pricing constitute a "Hobson's choice" for a dominant firm:

If the monopolist responds to the threat of potential competition by keeping prices low in order to ensure that it does not materialize as actual competition, he violates the law. If, disdainful of anyone's ability to challenge his position, he charges what the traffic will bear, his monopoly power is presumably "unreasonably" exercised. ${ }^{54}$

Operating under the threat of this "Hobson's choice," a rational management will respond to a treble damage complaint by "softening" its pricing strategy in a way calculated to deflect the plaintiff's charges.

The most difficult pricing allegation to defend against-and therefore the one with the highest risk factor-is "predatory" pricing. This allegation intimidates because of the vague or overly complicated definitions that are applied in determining illegality. Some of the decisions resolve the issue on the basis of the defendant's intent - a standard that is both nebulous and incapable of distinguishing anticompetitive pricing from efficient pricing. ${ }^{55}$ Although identification of inefficient pricing under cost analysis is a more rational technique, it is also more complicated. ${ }^{56}$ Thus, courts are actually motivated to revert to slippery evidence of "predatory purpose."

The capriciousness and inexactitude of determining predatory intent were revealed to risk-conscious firms in Telex Corp. v. International Business Machines Corp. ${ }^{57}$ Confronted with a declining share of the peripherals market, IBM formed a special "Peripheral Task Force"

51. 251 U.S. 417 (1920).

52. 110 F. Supp. 295 (D. Mass. 1953), affd per curiam, 347 U.S. 521 (1954).

53. Posner, supra note 49 , at 532.

54. D. Dewey, Monopoly in Economics and Law 239 (1959).

55. Judicial use of the term "predatory intent" is troublesome. Several cases hold that from a finding of certain actions, the trier of fact may infer predatory intent, and from this inference the proscribed inimical effects upon competition in turn may be inferred. However, application of these principles is particularly difficult, for predatory intent has never been clearly defined. Its appearance has been characterized by phrases such as "putting a crimp" into one's competitors, punitively or destructively attacking other firms, and acting vindictively with punitive effect. But any price decrease by a legitimately competitive firm will necessarily have a non-remunerative effect upon other firms in the market, if only by decreasing their profit margins.

International Air Indus., Inc. v. American Excelsior Co., 517 F.2d 714, 722-23 (5th Cir. 1975), cert. denied, 424 U.S. 923 (1976) (footnotes omitted).

56. This is well exemplified by the debate among Areeda and Turner, Scherer, and Williamson. See authorities cited in note 49 supra.

57. 367 F. Supp. 258 (N.D. Okla. 1973), modified, 510 F.2d 894 (10th Cir.), cert. dismissed, 423 U.S. 802 (1975). 
charged with the responsibility to develop "strategies to impede the growth of IBM's plug compatible competition." 58 Directing its attention to the objectives of the Task Force, the district court found that IBM's pricing policies were "predatory," despite the fact that IBM did not price below cost, and indeed, projected a twenty-percent profit. ${ }^{59}$ The Tenth Circuit Court of Appeals reversed, noting that "these acts ... are again part of the competitive scene in this volatile business inhabited by aggressive, skillful businessmen seeking to market a product cheaper and better than that of their competitors."

Pricing is also vulnerable to the convoluted provisions of the Robinson-Patman Act." ${ }^{61}$ Described as "one of the most tortuous legislative pronouncements ever to go on the statute books," son-Patman Act is generally recognized as constituting an unjustifiable impediment to competitive pricing. ${ }^{63}$ The twisted and varied interpretations of this complex law-"where, in some instances, violation can hardly be predicted"64_-compel even the most dynamic and risk-hardened manager to soften pricing policies upon the appearance of a complaint.

The most favorable environment for the use of the new antitrust strategy is in markets dominated by large firms. Closely scrutinized by ubiquitous reform groups and, in many cases, already saddled with a prior antitrust record with the government, large firms are psychologically conditioned to avoid potentially damaging confrontations with the antitrust laws. Judge Hand's suggestion in the Alcoa decision that dominant firms are bound to a higher standard of conduct in dealing with smaller rivals ${ }^{65}$ is now folklore. Every manager knows that maneuvers "honestly industrial" when practiced by a small firm take on antitrust coloration when performed by a large firm. ${ }^{66}$ Thus, large

58. 367 F. Supp. at 293.

59. Id.

60. 510 F.2d 894, 928 (10th Cir.), cert. dismissed, 423 U.S. 802 (1975). See 60 VA. L. Rev. 884 (1974).

61. 15 U.S.C. $\$ \S 13-13 b$, $21 a(1976)$.

62. J. Dirlam \& A. Kahn, Fair Competition: The Law and Economics of Antitrust PoLICY 119 (1954).

63. Levi notes that the Robinson-Patman Act "tends to be a price-fixing statute hiding in the clothes of anti-monopoly and pro-competiton symbols." Levi, The Robinson-Patman Act-Is It in the Public Interest?, 1 AnTitrust L.J. 61 (1952).

64. Report of the attorney General's National Commission to Study the AntiTRUST LAWS 378 (1955).

65. United States v. Aluminum Co. of America, 148 F.2d 416, 430-31 (2d Cir. 1945).

66. The real reason why some of the recent judgments in monopolization cases have caused criticism and controversy is indeed the fear of business people that 'normal methods of industrial development' have now been given so narrow a definition that a powerful firm has positively to 'pull its punches' to avoid giving an impression of unlawful intent.

A. NEALE, supra note 8, at 106. 
firms with dominant market power prove particularly susceptible to this strategy.

\section{B. The Emergence of the New Antitrust Strategy.}

Management received a quick education in the dynamics of modern antitrust strategy during the conglomerate merger wave of the 1960s. Borrowing from the exotic economic theories used by the government in its successful anticonglomerate blitz, many target firms employed antitrust litigation "defensively" to block takeover attempts by unwelcomed acquirers. ${ }^{67}$ The stereotype of the private action as exclusively a source of compensation was dispelled, and a new role was recognized: an antitrust complaint could buy valuable time to marshal resources and collect support to repel an invader. ${ }^{68}$ Experiences from the conglomerate wars taught managers that the antitrust statutes are flexible enough to support ingenious substantive theories and that the possibility of judicial acceptance of those theories can never be disregarded. ${ }^{69}$ They also learned that the subtleties of Industrial Organization Economics furnish a deep reservoir for imaginative theories that can be used affirmatively against rivals.

It did not take perceptive managers long to put their education to work for their practical advantage. The trade media now report on the aggressive antitrust activities of firms almost as frequently as they print new product announcements. The New York Times reports that "[c]ompanies are now willing to use private initiative-and their own dollars - to get relief from alleged monopolistic practices. Laws previously used to punish are now being used affirmatively." antitrust even seems to dominate a firm's competitive strategy. ${ }^{71}$

One of the most popular expressions of the new antitrust strategy

67. The classic example is Allis-Chalmers Mfg. Co. v. White Consol. Indus., Inc., 414 F.2d 506 (3d Cir. 1969), cert. denied, 396 U.S. 1009 (1970), where the Third Circuit Court of Appeals applied some "outer fringes" theories to help Allis deflect a takeover attempt.

68. See ABA Section of Antitrust Law, The Private Enforcement of Section 7 of THE Clayton ACT 29-32, 56-59 (Monograph No. 1, 1977).

69. See Austin, Conglomerate Merger: A New Source of Antitrust Tensions, 21 CASE W. REs. L. REV. 181 (1970).

70. N.Y. Times, Jan. $21,1973, \S 3$, at 1, col. 1. Barron's was more succinct: "What passes these days for anti-trust law . . . boasts many dubious aspects, but perhaps none so pernicious as the powerful incentive it holds out to litigious, dog-eat-dog competitors to employ it against their business rivals." Barron's, Aug. 21, 1978, at 7.

71. This is exemplified by the battle between H.J. Heinz Company and Campbell Soup Company, which have exchanged bitter charges of monopolization in an effort to gain market success through litigation. Wall St. J., May 30, 1978, at I, col. 6. Consistent with the innovative aspirations of the new antitrust strategy, Heinz alleges that one way Campbell monopolized was by using "saturation" advertising to sabotage its test marketing of a line of new soups. Id. 
is to frame allegations so as to impose an affirmative duty on dominant firms to protect smaller rivals from the possible adverse effects caused by the surprise introduction of new technology. Bell \& Howell's complaint against Eastman Kodak not only sought injunctive relief containing Kodak's future growth but also requested the court to order Kodak to publish advance information on new film. According to press reports of a 1974 settlement, "Kodak agreed to offer to Bell \& Howell and to other competitors advance information concerning Kodak's development of new film, when such film cannot be used in cameras already on the market." 72

The high antitrust risks confronting dominant firms and the "protectionist" demands of the new antitrust strategy were emphasized in Berkey Photo's successful jury verdict against Kodak. Berkey argued that Kodak had an affirmative duty to predisclose enough information on new products to allow rivals an opportunity to "compete on the merits."73 But perhaps the ultimate in "affirmative duty" arguments came from the Purex Corporation complaint which argued that "because of its dominant position, [Clorox] had an obligation to give $\mathrm{Pu}$ rex, a newcomer, an opportunity to get established in Erie before responding to the challenge." 74

The new antitrust strategy has also emerged in the computer industry where it has proven ominously successful. Since the government's monopolization complaint of 1969, IBM has been challenged in a growing number of private actions. According to Fortune magazine, "[1]ike Gulliver among the Lilliputians, International Business Machines is beset by a swarm of vengeful competitors who are trying to tie it down or break it up by antitrust decree."75 By attacking the legal propriety of IBM's pricing policies and its sales and distribution practices, smaller rivals have succeeded in inducing IBM to moderate the

72. Kohlmeier, Trust Busters Focus on Kodak, N.Y. Times, Nov. 21, 1976, at 1, col. 3.

73. Plaintiff's theory on the camera monopoly claim included the contention that if defendant had given them advance information about the size and other pertinent qualities of the new Kodakcolor II film, other camera manufacturers, including plaintiff, could have geared up to be ready to compete on the merits with Kodak in offering cameras suitable for use with the new film. Treating this aspect of the claim, the court cautioned the jury that a company normally has a perfect right to keep its secrets, winning competitive advantages by launching new and better products in its own way and in its own time. Undertaking, however, to apply the teachings of the authorities on Section 2 of the Sherman Act, the court went on to instruct that Kodak's monopoly power in film, if it was found to disable competitors who could not offer cameras comparable to Kodak's, might lead the judges of the facts to decide that the failure to give camera makers the necessary predisclosure concerning film should in all the circumstances be deemed anticompetitive.

Berkey Photo, Inc. v. Eastman Kodak Co., 457 F. Supp. 404, 414 (S.D.N.Y. 1978).

74. Purex Corp. v. Proctor \& Gamble Co., 419 F. Supp. 931,940 (C.D. Cal. 1976).

75. I.B.M.'s Travails in Lilliput, FORTUNE, Nov. 1973, at 148, 149. 
vigor of its competitive behavior. Conduct modification was also considered to be an important by-product of the Control Data complaint. Describing the "significant benefits resulting from the filing of our suit,"76 the president of Control Data observed that "we found that IBM marketing pressures that we had challenged lessened considerably."77 Fortune also detected the moderating consequences of private action pressures: "IBM tried to appease its critics by voluntarily reducing educational discounts and making other concessions to competitors."78 In addition, beginning in 1969, IBM stopped "bundling" its machine prices with its service prices and reduced the lag time between new product announcement and delivery so as to avoid "premature" product announcement allegations. ${ }^{79}$

The pretrial discovery process has given an additional edge to plaintiffs by enabling them to get an inside look at the style and planning attitudes of IBM's management. Of particular practical significance is the fact that rivals have gained access to candid selfevaluations of technology. For example, the trial court handling the Telex action allowed a trade association access to technological information that was subsequently published, much to IBM's chagrin. Especially embarrassing was an evaluation by IBM officials of its own equipment which concluded that it was "deficient" in comparison with rival goods. An industry observer suggested that the dissemination of this internal information was "one of the four or five worst things to happen to IBM in the last two decades." 80

From what is publicly known, it appears that the way to obtain the maximum advantage from filing a treble damage suit against IBM is to settle in exchange for various types of "business benefits." One of the most impressive "business benefits" was obtained by Control Data, which used the private suit as a lever to get IBM to sell its Service Bureau Corporation-formerly a competitor of Control Data's Cybernet business. As the president of Control Data correctly concluded: "The decision to file a lawsuit in 1969, although difficult at the time, has proved to be one of the best management decisions in our history." 11 Other plaintiffs have settled for less spectacular but equally significant benefits in the form of supply contracts, ${ }^{82}$ research and de-

76. Letter from William C. Norris, President, to Control Data Shareholders (Jan. 15, 1973) (on file with Author); see I.B.M.'s Travails in Lilliput, supra note 75, at 150.

77. Letter, supra note 76.

78. I.B.M.'s Travails in Lilliput, supra note 75, at 150.

79. G. Brock, The U.S. Computer INDUSTry: A Study of Market Power 180 (1975).

80. Wall St. J., Aug. 22, 1974, at 30, col. 1.

81. G. BROcK, supra note 79, at 172.

82. Applied Data Research, Inc. (ADR) settled for $\$ 1.4$ million as "reimbursement" for cer- 


\title{
velopment arrangements ${ }^{83}$ and technological exchanges. ${ }^{84}$
}

\section{Consequences of the New Antitrust Strategy}

\author{
The new antitrust strategy produces three negative effects. First, \\ the number of "tactical" lawsuits of less than marginal substantive
}

tain costs, plus the establishment of a business relationship with IBM. The president of ADR was quoted as saying that the two firms "are studying a business arrangement in which Applied Data Research would serve as a supplier of Autofiow . . . to IBM. This arrangement, when completed, will result in at least $\$ 600,000$ revenue to Applied Data Research over a period of three years." Wall St. J., Aug. 21, 1970, at 2, col. 2. Potter Instrument Co., a manufacturer of peripheral devices that can be attached to IBM's central computing units, announced that in exchange for a $\$ 3.5$ million contract to do "some product-development work" for IBM, it had dropped a state antitrust action and had decided not to file a federal antitrust suit that had been under consideration. Wall St. J., Oct. 15, 1973, at 11, col. 2. Sanders Associates received $\$ 10$ million in IBM business: $\$ 4$ million to develop computer-related products for IBM, $\$ 3$ million for "certain production commitments" and $\$ 3$ million in exchange for patents and products in Sanders' inventory. A Sanders official described the new association in these terms: "We feel the potential for substantial production and a future business relationship between IBM and Sanders makes this arrangement in the best interest of our company and its shareholders." Wall St. J., Jan. 28, 1977, at 4, col. 2.

83. Control Data Corp. settled for a variety of "business benefits," including four five-year research and development contracts and the sale by IBM to Control Data of its subsidiary, Service Bureau Corp., a supplier of computer services. The sales figure of $\$ 16$ million was the "book value," reportedly a very low estimate of the business value of the company. G. BRock, supra note 79 , at 172 . In addition, IBM agreed not to compete in the domestic data service market for six years, to pay $\$ 26$ million towards Service Bureau employee benefits and to purchase services from Service Bureau for the next five years. The Wall Street Journal concluded that the acquisition "may have boosted Control Data onto the top ring in the data-service industry." Wall St. J., Jan. 16, 1973, at 3, col. 1 .

The most controversial settlement term called for the destruction of Control Data's computerized trial information index. The index provided access to over 150,000 pages of IBM internal documents and other material obtained by Control Data through pretrial discovery. Claiming that the data bank had been an important source of information in its suit against IBM, the government charged that its destruction had a significantly adverse effect on trial preparation efforts. Wall St. J., Jan. 26, 1973, at 38, col. 2.

84. Under the terms of settlement between IBM and Sperry Rand Corp. (Sperry), the two companies entered into non-exclusive licensing agreements concerning the manufacture of punched-card accounting machines and electronic data processing machines. See Wall St. J., June 12,1964, at 14, col. 4. In addition, both parties consented to exchange detailed technical information, while IBM agreed to pay Sperry $\$ 10$ million over an eight-year period. G. BRock, supra note 79, at 167. As discussed at text accompanying notes 102-105 infra, subsequent litigation revealed that the licensing exchange and information sharing were an illegal restraint of trade.

Business Supplies Corp. of America and IBM settled a suit by agreeing to a cross-license patent for certain punched cards and the machines to make them. Wall St. J., Dec. 21, 1965, at 26, col. 3. In the Eaton Allen Corp. litigation, the settlement provided for Eaton to pay IBM $\$ 160,000$ over an eight-year period in exchange for licenses to manufacture existing typewriter ribbon cartridges. IBM received Eaton licenses for certain correctional material patents and agreed to pay Eaton $\$ 200,000$ for "ribbon development." Wall St. J., Apr. 28, 1975, at 15, col. 3. In a precomplaint settlement, IBM resolved antitrust and patent infringement allegations by Ampex Corp. with a cash payment of $\$ 13$ million and by agreeing to an exchange of patent licenses "covering their respective business interests in the data-processing field." Wall St. J., July 29, 1974, at 3, col. 1. According to a joint statement, "because of the exchange of licenses that will result, we believe that both companies will benefit." $I d$. 
merit is increased, thereby exacerbating existing problems. Second, skillful use of the new strategy fosters a "quiet life" of coexistence among former rivals. Finally, there is a clear danger that settlements will orchestrate the spread of the "quiet life," leading to a further moderation of competition or even to illegal restraints of trade.

\section{A. Existing Problems Exacerbated.}

1. Frivolous Claims. So long as the purpose of an antitrust suit is to intimidate the defendant in the exercise of his competitive instincts, the outcome on the merits is considerably less important than the pendency of the claim. Accordingly, there is a strong incentive to file marginal or meritless claims. This incentive is heightened by three additional factors. To the extent that managers adopt a risk-sensitive attitude towards antitrust claims, the costs to the plaintiff of supporting litigation will be made up in benefits from the "softened" competitive atmosphere. Moreover, because of the generality of the statutes and the choice of a wide range of precedent, it is relatively easy to develop a seemingly plausible rationale for a claim. Finally, because of the complexity of antitrust issues, courts are generally reluctant to grant the defendant's motions to dismiss or for summary judgment. ${ }^{85}$

2. Less Rational Antitrust Doctrine. Open-ended statutes give the courts wide discretion in evaluating claims. The Supreme Court has advised the bench and bar that the words of the Sherman Act have the "generality and adaptability comparable to that found to be desirable in constitutional provisions." Many courts have misinterpreted the Court's advice as an invitation to express value judgments in resultoriented opinions of limited coherence and predictability. The consequence is a crazy quilt of case law. ${ }^{87}$ By compelling the courts to evaluate self-serving and substantively unsound complaints, the new antitrust strategy makes a bad situation intolerable.

85. See Poller v. Columbia Broadcasting System, 368 U.S. 464, 473 (1962). Of course, attorneys should be cautious in forwarding frivolous claims on their clients' behalf since such conduct could run afoul of DR 7-102(A)(1) of the CODE OF PROFESSIONAL RESPONSIBILITY, which provides that "[i]n his representation of a client, a lawyer shall not . . . [f]ile a suit, assert a position ... or take other action on behalf of his client when he knows or when it is obvious that such action would serve merely to harass or maliciously injure another."

86. Sugar Institute, Inc. v. United States, 297 U.S. 553, 600 (1936).

87. Judge Wyzanski has acknowledged that a

District Judge knows that he cannot give any authoritative reconciliation of opinions rendered by appellate courts. And in connection with the Sherman Act, it is delusive to treat opinions written by different judges at different times as pieces of a jig-saw puzzle which can be, by effort, fitted correctly into a single pattern.

United States v. United Shoe Mach. Corp., 110 F. Supp. 295, 342 (D. Mass. 1953), affd per curiam, 347 U.S. 521 (1954). 
Antitrust law does not proscribe competitive warfare between firms. "It is competition, not competitors, which the Act protects." 88 Yet a complaint designed to block a rival's competitive tactics necessarily misdirects the court's attention from "competition" to the consequences of legitimate market rivalry. It encourages judges to find illegality merely from proof of the plaintiff's loss of business, a conclusion that "is itself profoundly anticompetitive." 89 Professor Posner has summarized the dangers:

Students of the antitrust laws have been appalled by the wild and woolly antitrust suits that the private bar has brought-and won. It is felt that many of these would not have been brought by a public agency and that, in short, the influence of the private action on the development of antitrust doctrine has been on the whole a pernicious one..$^{90}$

Over the long run, a constant stream of new-antitrust-strategy suits will have an adverse cumulative effect, ultimately engendering a negative reaction in the judiciary. Inundated with "intellectually disrespectable cases,"91 judges will develop a bias against the antitrust laws as a credible means of monitoring competition. The net result is the undermining of legitimate and responsible complaints, including those of governmental agencies responsible for protecting the public interest.

3. Delay. Antitrust suits are notoriously lengthy. ${ }^{92}$ The use of the new antitrust strategy will protract actions beyond the limits of tolerance. Typically, delay is a defensive tactic designed to drain the resources and wear down the resolve of the plaintiff. Where, on the other hand, the function of the suit is to soften "hard" competition, there is an incentive for the plaintiff to prolong matters by failing to pursue its claim aggressively and by acquiescing in the defendant's procedural ploys, thereby maintaining the influence of intimidation. Thus, for different reasons-plaintiff to sustain the threat and defendant to avoid the risk of treble damages-both sides decelerate the proceedings.

88. Brown Shoe Co. v. United States, 370 U.S. 294, 344 (1962). Unfortunately, the Court rejected its own advice by adopting a small-firm protectionist view.

89. Bork \& Bowman, The Crisis in Antitrust, 65 Colum. L. Rev. 363, 369 (1965). The authors condemn the creeping growth of the "injury to rivals" test.

90. R. Posner, Antitrust Law: AN Economic Perspective 288 (1976). Posner suggests that the Burger Court is more conservative than the Warren Court and thus may restrain the private bar. Id. 229.

91. Baker, Book Review, N.Y.L.J., July 7, 1978, at 2, col. 5.

92. The government's action against IBM is becoming one of the classic antitrust cases. The suit was filed in January 1969, and the trial slowly winds its way toward 1980. Assuming an appeal to the Supreme Court, "persons familiar with the suit now tentatively place the date [for a ruling] as sometime between 1985 and 1990." N.Y.L.J., Mar. 9, 1977, at 1, col. 2. 


\section{B. Anticompetitive Effects of the New Strategy.}

The new antitrust strategy can subdue competition. Confronted with a complaint, a risk-averting defendant will alter its behavior in a way calculated to pacify the plaintiff. Two of the most critical and visible manifestations of competition-pricing and technology development-are highly vulnerable to the new antitrust strategy. Since complaints involving these complex activities are viewed as posing a high risk of a successful treble damage award, conduct modification is deemed a rational alternative. One consequence is that important forms of competition are being tranquilized. Another effect is that firms are becoming reluctant to engage in the normal expressions of competition, opting instead for less detectable and, from a public interest standpoint, less desirable methods of obtaining business.

To a small number of frustrated managers, bribery and disparagement of rival products are attractive alternatives. However, the majority of firms will switch to risk-free tactics such as heavy advertising and product differentiation. ${ }^{93}$ Since none of the firms can accurately predict or measure the impact of product differentiation on sales or market shares ${ }^{94}$ this alternative constitutes an acceptable means of competing that is not likely to provoke rivals to retaliation.

In terms of the optimum allocation of resources, resort to productdifferentiation competition will prove to be wasteful at best and, in many instances, harmful to true competition. To the degree that the advertising budget emphasizes imagery and trivial distinctions-and passes on the cost to the consumer-resources have been inefficiently utilized. ${ }^{95}$ A more detrimental effect may come in the form of higher barriers to entry and in the intimidation of small rivals who do not have access to "deep pockets."

With respect to oligopolies, the prevailing view is that they are characterized by poor performance in important areas such as pricing and product innovation. ${ }^{97}$ In such markets, an important source of

93. In discussing the use of private antitrust actions against the "hard" pricing tactics of rivals, Elzinga concludes that "one unfortunate result of this type of suit will be a lessening of price competition, additional price rigidity, and a greater propensity for companies to use nonprice avenues of competition such as advertising and frivolous product differentiation." Elzinga, Panel Discussion: Private Action-The Purposes Sought and the Results Achieved, 43 ANTITRUST L.J. 73, 99 (1973).

94. See Austin, Antitrust Proscription and the Mass Media, 1968 Duxe L.J. 1021, 1031-33.

95. Scholars still argue over the effects of product differentiation and the extent to which it constitutes a waste of resources. See Industrial Concentration: The New Learning (H. Goldschmid, H. Mann \& J. Weston eds. 1974); Austin, supra note 94, at 1029-36.

96. See FTC v. Proctor \& Gamble Co., 386 U.S. 568, 578-79 (1967).

97. See R. Caves, American Industry: Structure, Conduct, Performance (4th ed. 
competition can come from small, dynamic and risk-preferring firms. The policy of the Justice Department is to protect and encourage such competition. ${ }^{98}$ However, when small firms exploit uncertainty and the large firms' vulnerability to the Alcoa obligations by filing meritless claims, these goals are undermined. By relying upon the new antitrust strategy to soften competition, small firms are foregoing an opportunity to become a dynamic factor in the market.

\section{The Use of Settlement to Establish "The Quiet Life."}

The goal of the new antitrust strategy is settlement in exchange for "business benefits." Given the trade-offs involved, settlement is the best risk solution for both sides. The defendant removes the risk of having to pay a treble damage award and simultaneously gains the opportunity to cultivate a "quiet life." In exchange for giving up a claim that drains resources and that may not produce a judgment, the plaintiff is rewarded with business advantages.

Settlement is especially attractive because, in most instances, the terms can be hammered out in the privacy of the boardroom without interference or supervision by a court, a governmental agency or rivals. ${ }^{99}$ Under Rule 41(a) of the Federal Rules of Civil Procedure, ${ }^{100}$ a non-class action plaintiff may withdraw, that is, may settle a suit, without court order either before an answer is filed or upon stipulation by the parties. Hence, while ostensibly ending a legal conflict to return to the marketplace for revival of the traditional competitive battles, firms can secretly effect contractual arrangements that might have adverse effects on the interests of rivals and the public. ${ }^{101}$

1977); C. Kaysen \& D. Turner, Antitrust Policy: AN Economic and Legal ANalysis (1965); F. SCHERER, supra note 20.

98. Under the "actual potential competition" doctrine the government seeks to encourage firms to enter new markets either de novo or by toehold acquisition. See United States v. Marine Bancorporation, 418 U.S. 602 (1974); United States v. Falstaff Brewing Corp., 410 U.S. 526 (1973).

According to Justice Department merger guidelines, the Antitrust Division will challenge mergers regardless of market shares where one of the firms is "unusually competitive." UNITED States Department of Justice, Merger Guidelines No. 8 (May 30, 1968), reprinted in [1977] 1 TRADE Reg. Rep. (CCH) I 4510.

99. The Sperry Rand-IBM settlement illustrates the advantages and ramifications of secret negotiations. Concerned that "the largest patent deal in history would not be well received by the public," Honeywell Inc. v. Sperry Rand Corp., [1974-1] Trade Cas. (CCH) I 74,874 at 95,914 (D. Minn. 1974), and recognizing that there would be serious antitrust problems if rivals sought, and were denied, access to the information covered by the license arrangement, id. at 95,913, IBM and Sperry "agreed upon a closely worded and innocuous-sounding press release . . . [that] did not contain enough information to make it self-explanatory nor to prevent it from being misleading as to the true content of the technological merger . . ." Id. at 95,920 .

100. Fed. R. CIV. P. 41(a).

101. Under these conditions, the settlement is a contract, rather than a judgment. THE PRI- 
In their most mischievous manifestation, settlements can be used to restrain trade in violation of the antitrust laws. In holding that the Sperry Rand-IBM accord ${ }^{102}$ violated the Sherman Act as a "technological merger," the district court described a laundry list of anticompetitive effects. "Technological peaceful coexistence" 103 between two firms controlling ninety-five percent of the industry stifled the growth of rivals and the industry. The combined technological portfolios gave the two firms an important advantage that had particularly serious effects on smaller rivals trying to compete in an infant industry. ${ }^{104}$ Not only was the dominance of the consortium assured, but the overall level of technological progress in the industry was also impeded. But for the dulling effects of the settlement, the incentive of each individual firm to innovate would have elevated the state of technology. ${ }^{105}$

While an individual settlement involving an exchange of business benefits may not constitute an illegal restraint of trade, a pattern of such settlements with smaller rivals could justify a finding that a dominant firm has monopolized trade in violation of section 2 of the Sherman Act. ${ }^{106}$ At the least, Alcoa and its progeny ${ }^{107}$ hold that a dominant firm cannot exploit "the advantage of experience, trade connections and the elite of personnel"108 to engage in exclusionary conduct that inhibits the competitive opportunities of smaller rivals. A policy of settling antitrust claims by establishing a variety of ongoing business relationships with rivals could constitute a form of exclusionary conduct. While the small firms are not excluded from the market, the ultimate effect might be to minimize their competitive impact. Doing business together will inevitably subdue the competitive antagonism between the firms, reduce the smaller firm's commitment to technological innovation and could eventually leave the small firm in a state of dependence.

VATE ENForCement of SeCtion 7 of THE Clayton ACT, supra note 68, at 19; see 5 MOORE's Fed. Practice \ 41.02(2) (2d ed. 1948).

102. See note 84 supra.

103. Honeywell Inc. v. Sperry Rand Corp., [1974-1] Trade Cas. (CCH) I 74,874, at 95,920 (D. Minn. 1974).

104. [S]ince 1956, all EDP industry members except IBM and SR (and CDC to a limited degree) have been operating under artificial EDP market constraints imposed by having had to compete against the combined technological portfolios of IBM and SR during the critical starting and developmental period of the EDP industry.

Id. at 95,918 .

105. Id.

106. 15 U.S.C. $\S 2$ (1976).

107. United States v. Grinnell Corp., 384 U.S. 563 (1966); United States v. Griffith, 334 U.S. 100 (1948); United States v. United Shoe Mach. Corp., 110 F. Supp. 295 (D. Mass. 1953), affd per curiam, 347 U.S. 521 (1954).

108. United States v. Aluminum Co. of America, 148 F.2d 416, 431 (2d Cir. 1945). 
A long-range ramification of this practice is that, as a dominant firm establishes a network of business relationships through settlements, the emergence of a marketwide ethos of accommodation becomes inevitable. The symbiotic association among rivals derived from ongoing business relationships will dull direct competition and discourage firms from entering markets where their "partners" are already operating.

\section{CONCLUSION}

The conventional assumption that the treble damage action polices the marketplace and deters violations is being rendered obsolete by the new antitrust strategy. An increasing number of firms are exploiting the private action to chill the competitive tactics of rivals. As a result, the negative trade-offs from reliance on a private enforcement system now outweigh positive effects. Under these conditions, serious consideration should be given to turning over to the government exclusive responsibility for enforcing the antitrust laws.

Exclusive reliance on the government would produce positive effects beyond the termination of existing defects in private enforcement. An expanded program, supported by a bigger budget, should generate a more effective detection system. Congress could be expected to furnish the resources to obtain the computer technology and other innovative supports necessary to streamline litigation. A centralized enforcement agency could coordinate and impose a coherent and unified policy that provides the business sector with clear signals on permissible conduct. Moreover, the government would be able to act as the exclusive antitrust advocate before the courts, increasing the likelihood that decisions would blend into a rational body of law. Finally, a single source of advocacy stands a good chance of bringing ideological differences into sharper focus, making it possible eventually to settle on a single goal. ${ }^{109}$

The hard reality is that, under the present political climate, repeal of private enforcement is unlikely. Congress is inclined to expand, rather than curtail, rights and remedies. ${ }^{110}$ This mood is supported by the vocal advocacy of the reformist-populist movement which holds that the treble damage action is an inherent right under the "economic

109. This is undoubtedly an overly sanguine projection. As Bork points out, the government has not made a strong record, frequently filing suits and presenting arguments that support the inefficient at the expense of free competition. R. BORK, THE ANTITRUST PARADOX: A POLICY AT WAR WITH ITSELF 415 (1978).

110. This is reflected in the Antitrust Improvements Act of 1976, Pub. L. No. 94-435, 90 Stat. 1383, and even more recently in S. 1874, 95th Cong., 1st Sess., 123 CoNG. REc. 12039-40 (1977). 
charter of freedom." In addition, an instinctive distrust of any extension of governmental power is likely to cost the support of the business community. Finally, given the government's weak record to date, projections of an effective program from an enlarged role in enforcement are suspect.

In the absence of termination of the private right of action, the new antitrust strategy will continue to produce adverse effects. By default, the burden of neutralizing these effects falls on the judiciary. As an opening step, courts should put plaintiffs to the test of proving harm to competition, rather than mere loss of business to competitors. ${ }^{111}$ In addition, a closer scrutiny of allegations and more frequent positive responses to motions to dismiss and summary judgment would make managers take a more realistic view of the results of instituting a treble damage action. The past record does not, however, indicate that the courts have the inclination or the expertise to sift out actions reflecting the new antitrust strategy from the valid claims.

The only tactic of the new antitrust strategy to which the application of a legislative remedy seems feasible is settlement. Opposition is unlikely to grow against a proposal that would not terminate the private right of action. The most feasible plan is to require the parties to submit copies of any proposed noncompensatory settlement to the appropriate court and to the Justice Department. The Justice Department would have sixty days to file a report with the court, summarizing the effects on competition and advising the court on the merits of the settlement. After receipt of the Department's report, the court would have thirty days to approve the settlement, taking into consideration its actual and potential effects on competition. The Antitrust Division would then be given thirty days after court approval to take formal action against the settlement. ${ }^{112}$

Two possible disadvantages must be weighed in assessing a court approval plan. If courts are conscientious in scrutinizing proposed settlements, an additional responsibility is added to an already burdensome workload. At the other extreme, some courts may avoid engaging in a thorough examination of competitive effects by perfunctorily granting approval of proposed settlements. However, any increase in the court's workload is counterbalanced by the involvement of the government. The court would have the benefit of the Justice Department's expertise and advice in evaluating the settlement, thereby reducing the

111. See Brunswick Corp. v. Pueblo Bowl-O-Mat, Inc., 429 U.S. 477 (1976).

112. This proposal is loosely patterned after the Bank Merger Act of 1966, 12 U.S.C. $\S 1828$ (1976), which requires the Justice Department to submit evaluations of the competitive effects of proposed bank mergers to the appropriate regulatory agency. 
burden on the conscientious judge and making perfunctory examination less likely. Another advantage is that the court can, where necessary, assure confidentiality. Finally, the involvement of the Antitrust Division is the most efficient means of assuring that the settlement is consistent with the public interest and the goals of competition. 